\title{
THE FOOD OF PORPITA AND NICHE SEPARATION IN THREE NEUSTON COELENTERATES
}

\section{$\operatorname{AUTHOR}(\mathrm{S}):$}

Bieri, Robert

\section{CITATION:}

Bieri, Robert. THE FOOD OF PORPITA AND NICHE SEPARATION IN THREE NEUSTON

COELENTERATES. PUBLICATIONS OF THE SETO MARINE BIOLOGICAL LABORATORY 1970, 17(5): 305-307

ISSUE DATE:

1970-02-21

URL:

http://hdl.handle.net/2433/175607

RIGHT: 


\title{
THE FOOD OF PORPITA AND NICHE SEPARATION IN THREE NEUSTON COELENTERATES ${ }^{1)}$
}

\author{
ROBERT BIERI \\ Antioch College, Yellow Springs, Ohio 45387
}

With 1 Table

On November 5, 8, and 9, 1965, small numbers of the oceanic chondrophore, Porpita, were blown onto the beaches of Shirahama together with other members of the neuston community. These included the purple snail, Ianthina, the nudibranchs, Glaucus and Fiona, the crab, Planes, the barnacle, Lepas, the siphonophore, Physalia, and the chondrophore Velella. This stranding provided an opportunity to close some of the gaps in our understanding of the neuston food web. The food and feeding habits of the Portuguese man-of-war, Physalia, are well known. In an earlier paper (BIERI, 1961) I reported some studies of the food of Velella, but I could find no reports of the food of Porpita.

As with Velella in the 1961 study, individual porpitas were collected alive from the sea surface, divided into four size groups, and preserved in formalin about onehalf hour after collection. In the laboratory the porpitas were measured and all the digestive appendages ("gonozoids" and the "oral chamber") were removed from each specimen. These dissected parts were examined under the microscope and parts showing any swelling or material inside were separated and opened. Dr. Abraham Fleminger very kindly identified many of the copepod remains.

The condition of the injested organisms varied from fragments of exoskeleton to complete, brightly colored specimens. The larger porpitas, like Velella, catch most of their food in the medusa bearing appendages, the "gonozoids". In small porpitas, the central "oral chamber" injests most of the food. The "oral chamber" usually contained one to three copepods while the "gonozoids" had an average of two to 43 food items depending on the size class.

It is clear that the vast majority of the food consisted of carnivorous calanid copepods (Table 1). These make up 90 percent or more of the diet in all sizes of Porpita. Crab megalopas and fish comprise about 10 percent of the food by count in the largest porpitas (mean diameter $31 \mathrm{~mm}$ ). I examined the feeding appendages of some porpitas 15 to $33 \mathrm{~mm}$ in diameter collected on November 5 and 8 and found

1) Contributions from the Seto Marine Biological Laboratory, No. 516.

Publ. Seto Mar. Biol. Lab., XVII (5), 305-307, 1970. (Article 19) 
Table 1. Food of Porpita specimens collected on November 9, 1965.

\begin{tabular}{|c|c|c|c|}
\hline $\begin{array}{l}\text { Average Diameter } \\
\text { of Porpita mm }\end{array}$ & $\begin{array}{l}\text { Number of } \\
\text { Porpita }\end{array}$ & $\begin{array}{l}\text { Food } \\
\text { Proportions }\end{array}$ & Copepod Species \\
\hline 1.8 & 3 & $\begin{array}{l}1 \text { pontellid } \\
1 \text { unidentified calanid }\end{array}$ & \\
\hline 18 & 17 & $\begin{array}{l}21 \text { pontellids } \\
22 \text { other calanids } \\
1 \text { megalopa }\end{array}$ & $\begin{array}{l}\text { Labidocera acuta common } \\
\text { Euchaeta marina common } \\
E \text {. acuta one } \\
E \text {. wolfendeni one } \\
\text { Candacia sp. one } \\
\text { Pontellopsis villosa one }\end{array}$ \\
\hline 24 & 7 & $\begin{array}{l}93 \text { calanids including } \\
\text { pontellids } \\
1 \text { corycaeid } \\
1 \text { barnacle cyprid }\end{array}$ & $\begin{array}{l}\text { Euchaeta marina common } \\
\text { Labidocera acuta common }\end{array}$ \\
\hline 31 & 7 & $\begin{array}{l}275 \text { calanids including } \\
\text { pontellids } \\
25 \text { megalopas } \\
2 \text { corycaeids } \\
1 \text { barnacle cyprid }\end{array}$ & $\begin{array}{l}\text { Labidocera acuta common } \\
\text { Euchaeta marina common } \\
\text { Candacia pachydactyla one } \\
\text { C. truncata one } \\
\text { Eucalanus crassus one } \\
\text { Labidocera kroyeri one }\end{array}$ \\
\hline
\end{tabular}

copepods, megalopas, larval fish, a gastropod veliger, a Lucifer, a Porpita medusa, two larvaceans, fish eggs and two chaetognaths. Nematodes and digenetic trematodes were also present, but in all probability are not food but parasites. In addition to the species listed in Table 1, Dr. Fleminger found Pontella chierchiae, Paracalanus and Undinula in the washings from these specimens.

The ability of Porpita to catch relatively large, active copepods stands in marked contrast to Velella in which copepods make up only ten percent of the food in the largest size class and two to three percent in the smaller size classes. It was indeed a surprise to find a Porpita $1.5 \mathrm{~mm}$ in diameter eating an adult pontellid copepod as big as itself. Just how porpitas, especially the small individuals, are able to catch these relatively large copepods is not clear. The rhythmic contractions of the tentacles described in detail by Mackie (1959) may trap them or possibly Porpita can detect vibrations in the water as Horridge (1966) has shown in the hydroid, Syncoryne, which is thus able to catch small active prey. On the other hand, the high incidence of sexually mature carnivorous copepods may indicate that these species are attempting to eat Porpita but are themselves trapped and eaten. The fact that Porpita catches mostly carnivorous copepods means that it is essentially a secondary carnivore like Physalia and Velella and not a primary carnivore as shown in the food web diagram I published earlier (BIERI, 1966).

It is clear that there is marked food selection in the three large neuston hydrozoans. Velella catches primarily passive food such as fish eggs and small larval forms of * crustaceans. Porpita catches active crustaceans, and Physalia catches fish. These differences begin when the youngest physalias, velellas, and porpitas appear at the sea surface and are essentially unchanged throughout their lives on the sea surface. 
The community of food organisms available to these forms is thus effectively divided among them producing three different food niches.

\section{REFERENCES}

BIERI, R. 1961. Post-larval food of the pelagic coelenterate, Velella lata. Pac. Sci., Vol. 15, pp. 553-556. 1966. Feeding preferences and rates of the snail, Ianthina prolongata, the barnacle, Lepas anserifera, the nudibranchs Glaucus atlanticus and Fiona pinnata, and the food web in the marine neuston. Publ. Seto Mar. Biol. Lab., Vol. 14, pp. 161-170.

HoRRIDGE, G.A. 1966. Some recently discovered underwater vibration receptors in invertebrates. In: "Some Contemporary Studies in Marine Science", H. Barnes (Ed.), Allen and Unwin Ltd., London, pp. 395-405.

MACKIE, G.O. 1959. The evolution of the Chondrophora (Siphonophora-Disconanthae) : new evidence from behavioural studies. Trans. Roy. Soc. Can., Vol. 53, ser. 3, pp. 7-20. 